\title{
Some Effects of Explicit Grammar Instruction and Syntactic Priming on Students' Written Language Production
}

\author{
Muhammad Asfah Rahman ${ }^{1}$, and Indrawaty $\mathrm{Asfah}^{2}$ \\ ${ }^{1}$ Faculty of Languages and Literature, Universitas Negeri Makassar, \\ Kampus UNM J1. A. P. Pettarani, Makassar, 90222, Indonesia \\ ${ }^{2}$ Faculty of Languages and Literature, Universitas Negeri Makassar, \\ Kampus UNM Jl. A. P. Pettarani, Makassar, 90222, Indonesia
}

\begin{abstract}
Structural or syntactic priming is a phenomenon in which prior exposure to specific language structures either facilitates or interferes with a learner's subsequent language production [1]. Exposure to English structures through explicit instruction is reported to have inconclusive results. [2] reported that explicit and implicit grammar instruction ends up with automatization. This study reexamines the effect of syntactic priming and explicit grammar instruction on students' writing. Specific grammatical features frequently appeared on TOEFL (Written Expression Section) test were intensively practiced and then the students took a test whose items were specifically collected from TOEFL practice tests. Finally, the students were assigned to write a short essay. Sentences with similar structures which the students had been exposed to were extracted from the students' essays. Out of 40 test items, only $59.86 \%$ in average could be answered correctly, and all of the grammatical features to which the students were previously exposed were contained in their essays. However, in average only eight out of 18 sentences were grammatically constructed. It can be concluded that although priming method with explicit instruction leads the students to use similar syntactic features in their writing, it seems to have little impact on students' grammatical knowledge for immediate use in written language production.
\end{abstract}

Keywords: syntactic priming, grammatical competence, EFL writing

\section{Introduction}

English as a required subject at junior and senior secondary schools in Indonesia seems to be an uninteresting subject for the majority of the students. Generally, English is formally introduced at the first year of junior secondary school. During this period, the students build up their interest and attitude towards the English subject. Positive attitude towards and high interest in the subject are to some extent shaped by their impression on the beginning English instruction. Their learning achievement may greatly be influenced by their attitude and interest. A survey conducted by [3] reveals that Indonesian junior secondary students had very poor mastery of their English materials, that is only around $30 \%$ for each of the four language skills. In 2016, [4] reported that after one year of English instruction in Junior secondary school, the students were still very poor in reading (only $39.54 \%$ letters correctly spelled, about $35.77 \%$ words correctly read/pronounced, only 
about $4.29 \%$ correct answers of reading comprehension questions, and only about $46.56 \%$ of dictated words correctly written). The English mastery that the students achieve at junior secondary becomes the basis for their further study at senior secondary schools and colleges.

The poor skills as foundation carried over from junior to senior secondary school level to a large extent influence the achievement of the students. [5] reported that senior secondary students had great problems when assigned to produce even simple sentences. They were unable to select appropriate words and put them into grammatical sentences. Most of the time, their sentences did not have any predicates, contained incorrect word order and subject-verb agreement.

The poor mastery of English of the secondary school graduates might be attributable to such factors as limited time of exposure to the language and lack of explicit instruction of particular language items, especially vocabulary and grammar. English is heard, spoken, or used only in the classroom. In six years, the students have four classroom hours every week or about 138 hours for one school year. Meanwhile, during the English lessons the teachers and the students do not use English all the time- they use both English and Indonesian. The limited time for English as dictated by the curriculum does not allow the teachers to practice explicitly such language items as forms and vocabulary which are the basis for developing the students receptive and productive language skills. It is realized that the adoption of communicative-based approaches emphasizes attention to communication with little or no attention to grammatical form.

Senior secondary school graduates who are admitted to university might have poor level of English skills. To determine the English language proficiency of the senior and vocational high school graduates who entered colleges, especially those who enrolled at English Department at the State University of Makassar, an assessment of the newly admitted students' English entry level behavior was carried out. The test was developed based on 1994 English curriculum for senior high school [6]. The study revealed that (1) the English mastery level of the freshman majoring in English (which once regarded as the entry level knowledge) only 45.31 per cent; (2) generally, the basic elements of grammar were not yet mastered by the students; the most problematic grammar items were, in the order of difficulty: gerund, verb followed by causative (e.g. "have"), passive sentence construction, use of tenses, sentence modality (conditional sentences), construction of compound sentences with conjunctions and sub-ordinator, and the relative and noun clauses; ( 3 ) the level of language skills of new students majoring in English in general was still weak. The mastery level of the material for each of the language skills was respectively speaking, listening, writing, and reading, while their level of vocabulary mastery was relatively the same, i.e. only 40.15 percent. Referring to [7], this mastery level belongs to frustrating level.

At the university, especially at the English Education Department the students are exposed to the language more intensively. They have particular courses on English structure and basic writing. Explicit instruction of English structure and writing is offered during their first four semester course of study. Therefore, they are expected to have sufficient grammatical knowledge and skills when they already complete the four semester courses. However, a recent study [8] reported that the students majoring in English did not apply correctly the grammatical items that they had learned in four consecutive courses when they were assigned to write. Among the most frequently grammatical errors commited by the students in their writing are verb tenses, sentences structure, subject-verb agreement, word order, pepositions, and determiners. 
Similar studies of linguistic errors are also widely practiced in other countries where English is taught as a foreign language. For example, [9] indicated that the first year students of English at Udon Thani Rajabhat University committed errors especially in the use of verb, noun, article, adjective, adverb, and sentence structure. Similar studies about students with different native language background documented relatively similar types of errors; for example, students of Saudi Arabia [10], students of of Iraq [11], students of Turkey [12], and students of Malaysia [13].

Investigation of the effects explicit grammar instruction on oral or written language production has revealed that there is no high quality evidence that teaching of traditional grammar or syntax (or the direct teaching of formal or generative/transformational grammars) is effective with regard to writing development [14]. This review article deals with students of ages 5 to 16 where English is their first language. Some recent studies investigating the role and impacts of grammar instruction in the context of English as a foreign language report some positive impacts of grammar teaching on writing. [15] reported that explicit teaching of collocation outperfomed implicit grammar teaching in paragraph writing of Iranian students. Another study by [16] and [17] found that explicit grammar instruction and grammar consciousness-raising tasks significantly improved students' grammatical knowledge, accuracy and fluency of writing. In Korean context, [18] reported that there was a positive impact of explicit grammar instruction on students' perception of their writing and editing abilities.

The discussion above may question the effects of explicit grammar instruction and the concept of priming method which suggests that language users' prior experience with language shapes their subsequent language use [19]. Despite long exposure to the language structure through explicit teaching and syntactic priming, the undergraduate students are still unable to produce the previously practiced syntactic structure in their written language production. The present study aimed to investigate the effect of explicit instruction and syntactic priming on graduate students' writing. The graduate students were required to have a minimum score of 500 on TOEFL test as a prerequisite for taking graduate courses. Therefore, they took TOEFL preparation course for three months. While attending the preparation, the researcher classified the syntactic structures most frequently appeared in the practice tests. For the purpose of this study, ten structural items were selected. They were (1) active-passive construction, (2) relative clauses, (3) suber-verb agreement, (4) tenses, (5) gerund and infinitive, (6) prepositions, and (7) word order, (8) conjunction, (9) verb form, and (10) word forms.

\section{Method}

Eighteen graduate students participated in the study. For three months, they were exposed to the ten selected syntactic structures through a variety of activities such as doing exercises from the TOEFL practice books, identifying the items from the reading passages provided by the researcher, intentionally learned and practiced the specified structural items from the assigned book (Structure and Meaning in English: A Guide for Teachers by Graeme Kennedy). At the end of the course, a structure test was administered to the group. (The test was a collection of 40 test items related to the ten selected syntactic/structural features the students had been exposed to from various TOEFL practice tests). This test was intended to assess whether the structural items were correctly identified as an indication that they already had knowledge and skills about the items. The following week, the students were assigned to write a short narrative essay of about 250 words about one of the most memorable experiences or events in their lives. The essays were examined whether they contained the ten tested syntactic structures that the students had been exposed to. 


\section{Results and Discussion}

This section consists of two parts. First, description of the result of the structure test. The second segment focuses on the narrative essays written by the participants.

\subsection{Structure test}

The result of the structure test is quite disappointing. None of the students answered all the test items correctly. The highest percentage of correct answers was $72.5 \%$ and the lowest was $45 \%$ items were correctly answered. The average correct answers was about $59.86 \%$. Fig. 1 shows the percentage of correct answers for each participants. The figure indicates that the students' performance on the test is far from satisfactory.

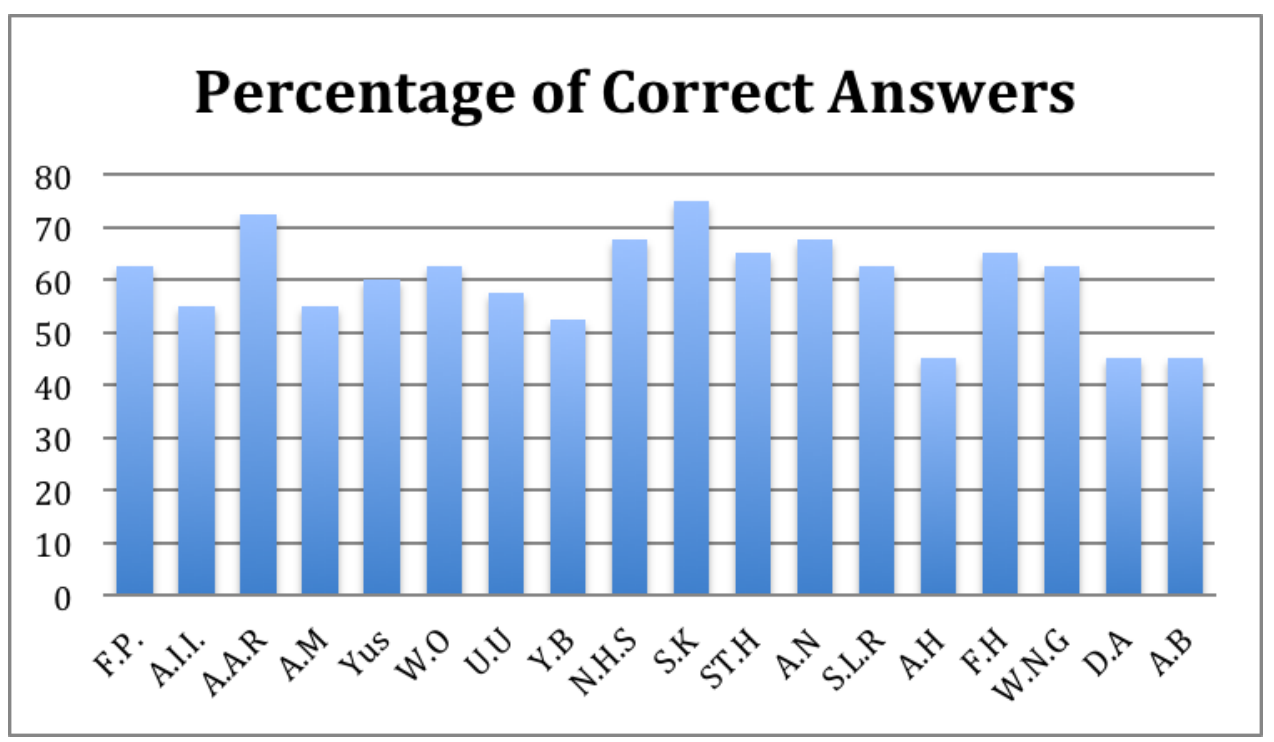

Fig. 1 Percentage of Correct Answers by Participants

Table 1. Number of Students' Correct Answers by Structural Features

\begin{tabular}{lcccccc}
\hline Structural Items & Q1 & Q2 & Q3 & Q4 & Q5 & Q6 \\
\hline Active-passive & 14 & 18 & 15 & 8 & & \\
Conjunction & 7 & 13 & 9 & 8 & & \\
Gerund/Infinitive & 14 & 13 & 8 & 8 & 15 & \\
Relative clause & 8 & 10 & 9 & 14 & 13 & 7 \\
S-V Agreement & 10 & 6 & 11 & & & \\
Tenses & 11 & 8 & 16 & 6 & 10 & \\
Word forms & 16 & 15 & 4 & & & \\
Verb forms & 10 & 13 & 7 & 15 & 15 & \\
Preposition & 3 & 11 & 15 & & & \\
Pronoun & 16 & 6 & & & & \\
\hline
\end{tabular}


Table 1 shows the number of students that answered correctly the test items on each structural features. The table indicates that the students' performance is not consistent yet. For example, all students answered correctly question 2 (Q2) but some of them answered incorrectly the other three questions for the same active-passive construction. The figure also indicates that there might only be eight out of 18 students who consistently answer correctly the active-passive items. Similar phenomenon can be observed in all types of structural items.

\subsection{Short Narrative Essay}

The students' narrative essays contain all the structural aspects to which they have been exposed. The number of sentences and the number of correct sentences that each participant produced can be seen in Fig. 2.

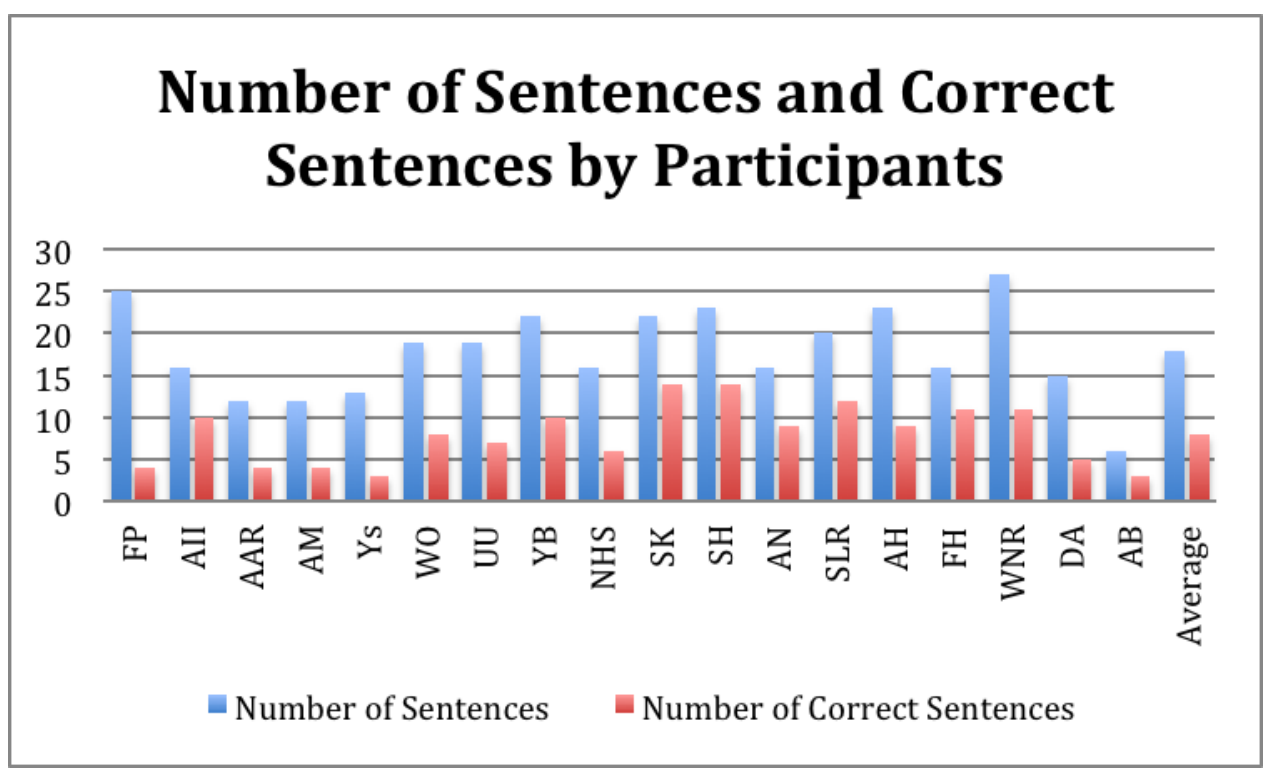

Fig 2. Number of Sentences and Correct Sentences by Participants

Fig. 2 shows that in average number of sentences that the students produced is about17.89, of which only 8 (44.72\%) sentences in average are grammatically constructed. As expected the students used almost all of the syntactic features that they had been exposed to through various ways. The students tend to produce the recently practiced syntactic structures in their subsequent written expressions as found in their essays. However, many of their sentences are not well-formed - do not fully attend to the rules of the intended syntactic structure.

Following are some sample sentences extracted from the students' essays.

A student participant who correctly identified the answer of a passive form on the structure test (Question: Aspirin used to lower fever, relieve pain, reduce inflammation, and thin the blood; Answer: Aspirin is used to lower fever, relieve pain, reduce inflammation, and thin the blood.) writes the following sentence in his essay:

*This program called "BRIDGE" Building Relationship Intercultural Development and Growing Engagement.

It should be: This program is called "BRIDGE" Building Relationship Intercultural 
Development and Growing Engagement.

*My school SMPN 7 Pattallassang in Gowa region was choose as one of the school in Indonesia to have a sister school in Australia. (was chosen)

Examples of other syntactic structure are shown below.

Subject-verb agreement:

*Development of any nations is determined by leader who are in charge of managing the economic, political and social aspect of the country. (leaders who are) or (a leader who is)

*An education equips a person with the necessary attributes with enables them to be compatible with the society. (... the necessary attributes which enable ...)

* Education gives people skill and knowledge that helps them in solving the problems which affect them. (skill and knowledge that help)

Word form :

*It was an embarrased moment. (embarrassing)

*I felt very pain on my leg. (painful)

Relative clause:

*A country will choose its leader whom has good understanding about government and the regulation. (who)

*It was an international school where was located on J1. Botolempangan No. 45 Makassar. (that or which)

Conjunction (complex sentences)

* It was very pleasure, because I enjoyed learning and practicing. (It was so pleasing that I enjoyed learning and practicing.) or (Since it was very pleasing, I enjoyed learning and practicing.)

* I have no worry about the finance, Australian government funding this program fully.

(I have no worry about the finance because (or since) Australian government funds this program fully.)

This study reveals that explicit grammar instruction together with syntactic priminng encourages the students to produce sentences which contain the syntactic structure they are exposed to. Consequently, their essays contain a variety of sentence types. Yet, the kinds of exposures including practices, identifying the structures out of the reading passages, and self-study on particular grammar books seem to have not created sufficient grammar knowledge for practical application on writing tasks. The use of a wide range of syntactic structures does not follow each structure item used in the essays. Thus explicit instruction and priming method in English as foreign language produce relatively the same results as those studies reviewed by [20]. Grammar teaching does not provide significant evidence that it improves quality and accuracy in students' writing in English as a first or a foreign language.

\section{Conclusion and Implication}

The result of this study confirms that explicit grammar instruction plus syntactic priming encourages the students to use the structures that they are exposed to. All of the syntactic structure items to which the students are exposed to are found in their essyas. This indicates 
that priming and explicit instruction have positive effect on students' writing in terms of language use or sentence varieties. However, the accuracy of expressions in the written forms is not yet guaranted. For accuracy, there should be other activities which emphasize the development of rule accuracy, especially for complex sentence construction. The activities should raise the students' awareness of the grammatical rules, their functions and meanings.

This study involves too many syntactic structure items in the priming and therefore it does not meet the principle of mastering one item before moving to another item. Immediate application of the syntactic structure in productive language tasks should always follow to ensure accurate use of the structure. Tasks should be designed which require the students to apply the newly primed syntactic structure which will in turn become part of the students' tacit knolwedge.

\section{REFERENCES}

1. P. Trofimovich, K. McDonough. Priming Research. In C.A. Chapelle (Ed.) The Encyclopedia of Applied Linguistics. Blackwell Publishing Ltd. (2013).

2. B. Tutun. Int. J. Hum. Sos.Sc. 2, 5 (2012).

3. E. Sadtono, et al. Survei Diagnostik Bahasa Inggris dan Rekomendasi untuk Program Pelatihan In-Service untuk Dosen/guru SLTP. Technical Report No. 8b. Central Program Coordination Unit (CPCU), Junior Secondary Education Project, Ministry of Education and Culture, Indonesia (1997).

4. M. A. Rahman. Reading in English as a Foreign Language: A Case of First Year Students of Junior Secondary Schools in South Sulawesi, Indonesia. Asia Pacific Journal of Contemporary Education and Communication Technology Year 2/Volume 2/Issue 03 (Special Issue), pp. 15-21 (ISSN: 2205-6181. (2016).

5. M.A. Rahman \& Mustamir. Word-Attacks in Action: Improving the Reading Comprehension Skills of the Students of SMU Negeri II Makassar. Laporan Penelitian, Lembaga Penelitian UNM. (2003).

6. M.A. Rahman, M.A. Rasyid. Bekal ajar awal mahasiswa angkatan 2001/2002 Jurusan Bahasa Inggris Fakultas Bahasa dan Seni Universitas Negeri Makassar. 2001. Laporan Penelitian: Lembaga Penelitian UNM (2001).

7. W.H. Miller Reading Diagnosis Kit. USA: The Center for Applied Linguistic in Education, Inc. (1978).

8. M.A. Rahman, M.N. Sainu, I. Asfah. Revisiting the Linguistic Errors in the Writing of the Students Majoring in English. Paper presented at the $2^{\text {nd }}$ ICEST. (2016)

9. K. Nonkukhetkhong. Grammatical Error Analysis of the First Year English Major Students, Udon Thani Rajabhat University. The Asian Conference on Language Learning 2013: Official Conference Proceeding: pp. 117-126. (2013).

10. M. H.M. Sawalmeh. Error Analysis of Written English Essays: The case of Students of the Preparatory Year Program in Saudi Arabia. English for Specific Purposes World, ISSN 1682-3257, http://www.esp-world.info, Issue 40, vol. 14 (2013).

11. M. Q. Mohammed. Error Analysis: A Study on Grammatical Errors in the Writings of Iraqi EFL Learners. European Academic Research. Vo. III, Issue 11/February 2016: 11648-11668. (2016) 
12. I. Abushihab. An Analysis of Grammatical Errors in Writing Made by Turkish Learners of English as a Foreign Language. International Journal of Linguistics. Vol. VI, No. 4. pp.213-223. (2014).

13. A. Y.H. Tse. A Case Study of Grammatical Errors Made by Malaysian Students. International Journal of Science Commerce and Humanities: Volume No 2 No 5, July 2014: pp. 154-160 (2014).

14. Andrews R, Torgerson C, Beverton S, Locke T, Low G, Robinson A, Zhu D. The effect of grammar teaching (syntax) in English on 5 to 16 year olds' accuracy and quality in written composition: Review summary. University of York, UK. (2004).

15. M. Karami. Exploring Effects of Explicit vs. Implicit Teaching of Collocations on The Writing Performance of Iranian EFL Learners. International Journal of Language Learning and Applied Linguistics World (IJLLALW) Vol. 4(4) (2013).

16. P. Rajabil, E. Dezhkam. The Effect of Explicit Grammar Instruction on Improving Writing Accuracy of Iranian EFL Learners. Journal of ELT and Applied Linguistics (JELTAL) Volume 2-Issue 1, (2014).

17. M. Nosratinia, S. Roustayi. The Effect of Grammar Consciousness-Raising Tasks on EFL Learners' Reading Comprehension and Writing Ability. IOSR Journal Of Humanities And Social Science (IOSR-JHSS) Vol 19(3). (2014)

18. G.H. Wang, S-D. Wang. Explicit Grammar Instruction for EFL Writing and Editing: An Exploratory Study at a Korean University. Linguistics and Literature Studies 2(2): 65-73. (2014).

19. P. Trofimovich, K. McDonough. Using priming methods to study L2 learning and teaching. In P. Trofimovich, K. McDonough (Eds). Applying Priming Methods to L2 Learning, Teaching, and Research. John Benjamin Publishing Co. (2011).

20. Andrews R, Torgerson C, Beverton S, Locke T, Low G, Robinson A, Zhu D. The effect of grammar teaching (syntax) in English on 5 to16 year olds' accuracy and quality in written composition: Review summary. University of York, UK. (2004). 